DOI: $10.1515 / \mathrm{rpp}-2015-0065$

Candidate of Psychological Sciences, Associate Professor, KATERYNA SKYBA

Khmelnytskyi National University, Ukraine

Address: 11 Instytutska St., Khmelnytskyi, 29016, Ukraine

E-mail:katrusyk@gmail.com

\title{
KEY METHODOLOGICAL ASPECTS OF TRANSLATORS' TRAINING IN UKRAINE AND IN THE USA
}

\begin{abstract}
The diversity of international relations in the globalized world has influenced the role of a translator that is becoming more and more important. Translators' training institutions today are to work out and to implement the best teaching methodology taking into consideration the new challenges of modern multinational and multicultural society. The thorough research of the experience in training translators and interpreters in the USA may help to find out new perspective methodological approaches to teaching and learning. This article reviews the variety of translator training programmes in Ukraine and in the USA and presents the analysis of the innovative teaching approaches that are currently popular in the education community. There exist different kinds of translators' training degree programmes: short and long, full-time and part-time in Ukraine and in the USA. American universities and colleges provide not only academic programmes but also specific certificate programmes in translation and interpretation. The peculiarity of Ukrainian translators' training programmes is that all these programmes are fully integrated into the university system. The approaches applied in the process of translators' training in the American system of education are mostly new and oriented on the professional skills building. The following teaching approaches are currently used in the translators' training process: profession-based, learner-centred, social constructivist and interdisciplinary. A social constructivist approach is more likely to be applied to translators' training process in Ukraine under the modern conditions.

Key words: translators' training, translators' training program, approach to translators' training, profession-based, learner-centred, interdisciplinary, social constructivist.
\end{abstract}

\section{INTRODUCTION}

Globalization processes have influenced communication and increased the role of translators who transmit information between people, nations, and countries. Employers and occupational researchers in Ukraine emphasize that at present translators' training is not adequate for the reality of professional life. Thus, the main task of domestic educational system is to elaborate the teaching methodology that would meet the demands of the harsh reality of future professional needs. The thorough review of the new approaches to teaching translation experience in the USA may help to eliminate perspectives for Ukrainian system of translators' training

\section{THE AIM OF THE STUDY}

The aim of the study is to review the variety of translators' training programs in the USA and Ukraine and to analyze the new modern approaches to teaching translators and interpreters in the USA that can be applied in Ukraine. 


\section{THEORETICAL FRAMEWORK AND RESEARCH METHODS}

The theoretical basis of the study are the works of American and Ukrainian scholars on the problems of translators' training process, development of translators' training programmes and study the range of methodological approaches applied. Under the conditions of higher education reformation in Ukraine the domestic scientists are interested in the foreign positive experience and are actively carrying out a comparative-pedagogical study of specialists' professional training in the education systems of developed countries: the USA, Germany, Canada, France, Great Britain, China, Australia, Scandinavia, Poland (N. Avshenyuk, N. Bidyuk, Yu. Golovatska, V. Kudin, M. Leschenko, O. Martyniuk, A. Matvienko, N. Mukan, N. Nychkalo, O. Ohiienko, I. Rusnak, N. Paziura, O, Sierhieieva, O. Tarasova, A. Sbruyeva and others). Some aspects of professional translators' training in the USA have been the subject of research of L. Chernovaty, O. Martyniuk, R. Sharan. Of great interest are the results of foreign scientists' researches such as J. Casey, T. Kearns, D. Kelly, D. Kiraly, H. Lee-Jahnke, B. Sawyer, A. Selcen, M. Snell-Hornby, G. Tareva, M. Tennet, J. Varney, E. Zeer and others.

The research methods we used are: theoretical analysis, comparative analysis, synthesis, the method of studying educational documents.

\section{RESULTS}

The translators' training courses appeared not too long ago. Thus, the methodology for the translators' training has not been properly developed yet. The latest researches (Casey, 2009) show that most of the academic courses are usually focused on translation study and translators' training. The market of translation services has changed extremely over the last two decades under the influence of worldwide globalization and the development of international and intercultural relations in different spheres of life. Today a translator or interpreter should not only be professionally trained to translate or to interpret but also know how to use new informational technologies, how to lead business and be aware of the most important economic trends in the world. All this means that the translators' training programmes should be aimed at training a specialist that meets the demands of a new globalized society.

There have been a number of discussions on translation and interpretation teaching methods. Many researchers have considered the curriculum and syllabus design, the importance of usage of new informational technologies in the process of training (Selcen, 2014). Not all translators' training programmes have the same form. National contexts and traditions mean that some of them are full undergraduate courses (Germany, Belgium, Spain, Canada), while others are postgraduate (France, US, Ukraine, and many but not all UK courses). In Ukraine training programmes are fully integrated into the university system and usually include a higher proportion of theoretical elements. In the USA there exist also other programmes that are offered by institutions which do not belong entirely to the university system, granting vocational diplomas which do not lead on to postgraduate education (Kelly, 2005). The aims of the programmes are also different. For example, in Ukraine the programmes are focused on very generalist training, when in the USA the programmes usually provide training in specific areas of translation (literary translation, technical translation, legal translation, audio-visual or screen translation, conference interpreting, and community interpreting). Length of the programmes varies from short one-year courses to long courses of up to five years.

In Ukraine the training programmes are designed for students (usually young people at the age around 18-25) who wish to become interpreters or translators through part-time or full-time degree programmes. The similar programmes are provided by the 
American universities and colleges. Thus, in a number of universities and colleges the programmes last from two to four years of full-time studies (two years at graduate level and three or four years at undergraduate level). But at the same time, there are a lot of programmes for students who have already tried themselves as translators or interpreters. For those who have some professional experience there exist short degree and certificate programmes. However, most of the certificate programmes extend over two to four years

Today we need to train future translators/interpreters able to act independently, take a distinctive position, to be business leaders of the new generation. They must be ready for self-realization and be people willing to innovate. Thus, it is worth analysing innovative new modern approaches to translators' training. Science of teaching translation - Translation Didactics - includes a variety of teaching approaches. The parameters of innovativeness of the approaches in General Didactics described by E. Zeer (Zeer, 2011) cited in the work by E. Tareva and B. Tarev "Innovative Approach to Teaching Translation and Interpreting" are as follows: 1) relevance: the approach meets social requirements that determine the need for younger generation to be ready for participation in cross-cultural communication; 2) novelty: the approach is completely different from what was used earlier; 3 ) productivity and efficiency: long-term and multiple studies support the effectiveness of the approach in the process of education; 4) optimality: the acceleration of skills development, saving mental, emotional efforts of students; 5) educational value: the approach has a direct impact on development, education, and training of students; 6) practicability: should be obvious practical value of the approach; 7) feasibility: the innovation is realistic, it is reproducible in different educational contexts, does not require much effort, retraining of teachers, introduction of absolutely new and costly training facilities; 8) non-obviousness: the approach is not a truism; in that interpretation it has never been assessed by anyone due to fundamentally different interpretations admitted by the absolute majority of its supporters.

Thus, the approaches to training translators/interpreters should be considered according to the abovementioned parameters to decide whether they are really innovative and effective. As the limits of the article do not allow us to consider all the approaches that are used in translators' training process in the US system of education, we will only analyse those that are popular and new.

Since 1990 a strong shift from teaching to learning occurred. It means that teaching aims at an individual learning process in which the trainer acts mainly as facilitator. This implies that no more the trainer but the student is in the centre of the process. The trainer helps mainly in the knowledge and skills transfer, shows how to integrate actively new knowledge into existing knowledge (Lee-Jahnke, 2011). Profession-based learner-centred approaches are the approaches of this kind. These approaches are based on the premise that training should simulate professional practice. According to these approaches students are supposed to solve realistic translation tasks designed to develop translator competence. Among the profession-based approaches the one proposed by Nord (1996) is very famous. This approach is a clear move towards student-centred teaching/learning, and towards professional realism in the classroom. We also support the idea that the Nord's approach implies the gradual nature of the acquisition of translator competence, and the need for considerable teacher intervention, particularly in the early stages, to ensure that tasks are not only realistic, but also feasible and hence not de-motivating. As D. Gile (Gile, 2009) rightly points out, the approach oriented on the process is good at the beginning of the course. Starting at the middle of the course, the instructors need to start focussing on the product (ready translation or interpretation) and analysis of its quality, relevance and the 
way it was performed. The product-oriented teaching suggests the instructors' comments on the strategies and tactics used by the students in the process of translation or interpretation and proposals of possible variants of solutions to specific translation/interpretation difficulties. We support the idea that the trainer nowadays should be a facilitator who only helps students to develop their professional personality.

A social constructivist approach to translator education elaborated by D. Kiraly is for translators' trainers who are looking for new efficient approaches to translator education. In this regard, a social constructivist approach is a very promising one. The method suggests the "scaffolding" learning through which the students may form and develop the competences needed to solve old and new translator tasks (Kirally, 2000). D. Kiraly proposes to focus on the learning process and to change the role of a teacher from the transmitter of knowledge into a guide, consultant and facilitator. This will foster students' autonomy and help them to become full-fledged translators and interpreters. The researcher also emphasizes the importance of translation activities that should be real and reflect the future professional tasks.

The main principles of the method developed by D. Kiraly are as follows: 1) to situate authentic learning experiences; 2) learning experiences of this kind always have multiple perspectives; 3) learning experience must include collaborative work; 4) elaboration of multiple and viable solutions to problems that emerge naturally from authentic projects (instead of a correct solution); 5) the teachers should create a basis (scaffold) for learning from the beginning of the course and then gradually release control over the learning environment to the students themselves (Rosas, 2004). The social constructivist approach equips students with necessary professional competencies and helps them to adapt to the conditions of future professional environment.

An interdisciplinary approach is supposed to be new and promising for academic training in translation. According to J. Casey the traditional methodologies usually concentrated on only one specific discipline may have bad influence on students' education. The interdisciplinary approach is a beneficial one and develops lifelong learning skills that are very important for the translators' future learning and self-realization. However, this approach has become an important and challenging technique in the modern curriculum. It suggests the combining of disciplines and the teachers and students cooperation aimed to organise the learning process in an interdisciplinary fashion. J. Casey emphasizes that this approach is different from a multidisciplinary approach. Interdisciplinary techniques allow students working individually or in groups by making the synthesizing of disciplines to realize the challenging tasks and to take viable solutions. We also support the idea that interdisciplinarity is the key to new approaches and hence new findings and innovative didactical methods within the framework of translation (Lee-Jahnke, 2011). But we must admit that many researchers find not only advantages, but also disadvantages of interdisciplinary studies. The timeconsuming process of curriculum designing that involves collaborative work of a group of teachers is usually regarded as a disadvantage of this approach. But nevertheless the interdisciplinary approach provides many life skills that are appreciated by educational institutions and employers.

\section{CONCLUSIONS}

The conclusion that the author wishes to draw here is that it is a difference in translators' training programs in Ukraine and in the USA. The Ukrainian programs are mostly focused on generalist training when in the USA the programs are focused on specific areas of translation or interpretation. The length of programs in Ukraine varies from one and a half year to four years depending on a degree the students will obtain after finishing the programme. The peculiarity of Ukrainian translators' training programs is that 
all these programs are fully integrated into the university system. In the USA except similar programs there exists a big choice of different types of certificate programs that are not always provided by the universities or colleges. The approaches applied in the process of translators' training in American system of education are mostly new and oriented on the professional skills building. A social constructivist approach is becoming more and more popular nowadays. It equips students with the necessary professional competencies relevant to the up to date translators' tasks. This approach focused on future translators' professional activity may be successfully applied by Ukrainian instructors of future translators and very effective. Of course, the thorough research of today's labour market and the range of fictional responsibilities and variety of professional activity of a modern translator and interpreter should be done at the first stage. The next stage will include educational program and curriculum designing. The interdisciplinary approach affects the curriculum designing process. It suggests team-teaching when teachers from different disciplines work together to design a curriculum. This approach has its advantages and disadvantages. From one point of view, it is a time-consuming procedure to design an interdisciplinary curriculum. From other points of view, it is a very promising approach that provides skills that are highly valued by top colleges and business. This approach may be applied to Ukrainian system of translators' education step by step as it involves a collaborative work of teachers in a number of departments in an education institution.

\section{REFERENCES}

1. Casey, J. (2009). Interdisciplinary Approach - Advantages, Disadvantages, and the Future Benefits of Interdisciplinary Studies. ESSAI, Volume 7, Article 26. Retrieved 15.08.2015 from : http://dc.cod.edu/essai/vol7/iss $1 / 26$

2. Gile, D. (2009). Basic Concepts and Models for Interpreter and Translator training. Amsterdam, Philadelphia : John Benjamins, 283 p.

3. Kelly, D. (2005). A Handbook for Translator Trainers. A Guide to Reflective Practice. Manchester : St Jerome Pub, 173 p.

4. Kiraly, D. (2000). A Social Constructivist Approach to Translator Education. Empowerment from Theory to Practice. Manchester, UK : St. Jerome Publishing, 216 p.

5. Lee-Jahnke, H. (2011). Interdisciplinary Approach in Translation Didactics. International Journal of Translation, No 1, pp. 1-12. Retrieved 05.09.2015 from : http://e tabeta.univ.trieste.it/dspace/bitstream/10077/9172/1/01-Interdisciplinary-Hannelore_Lee_Jahnke.pdf

6. Nord, C. (1996). Translating as a Purposeful Activity. Functionalist Approaches Explained. Manchester : St. Jerome, 160 p.

7. Rosas, M. (2004). Don Kiraly's a Social Constructivist Approach to Translator Education. Translation Journal, Volume 8, No 4. Retrieved 05.09.2015 from : http://accurapid.com/journal/30review.htm.

8. Selcen, A., Eryatmaz, S. (2014). An Interdisciplinary Approach for Academic Training in Translation: Legal Translation as a Specialized Translation Course. Journal of Language and Literature, Volume 10, pp. 69-75.

9. Tareva, E. G, Tarev, B. V. (2014). Innovative Approach to Teaching Translation and Interpreting. Journal of Siberian Federal University. Humanities \& Social Sciences, No 2, pp. 326-333.

10. Зеер, Є. Ф., Новоселова, С. А., Давидова, Н. Н. (2011). Институциональное обеспечение образовательных инноваций [Institutional Provision of Educational Innovations]. Education and Science, No 9 (88), pp. 3-20 (in Russian). 